\title{
Gender Violence in the Women of Azogues
}

\author{
María de los Ángeles Estrella-González ${ }^{1,2,4 *}$, Isabel Cluet de Rodríguez ${ }^{1}$, Paola Elizabeth Pérez-Uchuari², Mónica Viviana \\ Siguenza-Bermeo ${ }^{2}$, Andrés Alexis Ramírez-Coronel ${ }^{2,3,4}$ \\ ${ }^{1}$ Doctorate in Health Sciences, University of Zulia, Venezuela. \\ ${ }^{2}$ Faculty of Nursing at the Catholic University of Cuenca, Azogues, Ecuador \\ ${ }^{3}$ Psychometrics Laboratory of the Center for Research, Innovation and Technology Transfer, Cuenca, Ecuador \\ ${ }^{4}$ PEPLAU Research Group
}

\begin{abstract}
Gender violence is an issue that generates worldwide impact, in addition to being a public health problem, since there are high levels of patrimonial, psychological, physical and sexual violence that occur daily and are not reported due to fear, omission and Justification, that is why the importance of carrying out this research is born. Describe gender violence in women who attend the Health Center No. 1 of Azogues. Non-experimental study of descriptive, analytical, prospective and cross-sectional type with a quantitative approach. The participants were Women 15 to 49 years of age who went to an outpatient clinic. A survey was designed that included sociodemographic factors and consisted of 27 questions, which collected data on the types of patrimonial, psychological, physical and sexual violence. Results were obtained from 351 women who made up the established sample, where more than $50 \%$ belonged to the young adult population, they showed patrimonial violence $22.5 \%$, Psychological $45.6 \%$, Physical $20.8 \%$ and sexual 13, one \%. There is a level of positive significance between age and patrimonial, psychological and physical violence, marital status with all types of violence and the level of instruction with a level of negative significance related to patrimonial, psychological and physical violence.
\end{abstract}

Keywords:- Gender violence, Women, external consultation.

\section{INTRODUCTION}

In 1994, the Pan American Health Organization, in the Declaration of the Inter-American Conference on Society, Violence and Health, recognized violence as a problem that affects the entire population. At the United Nations International Conference on Population and Development held in Cairo, it was recognized that reproductive rights are human rights, that gender violence is an obstacle to women's reproductive rights, sexual health, education, participation and development (1).

Gender violence is considered a human rights and public health problem, mainly affecting women around the world regardless of social class, ethnicity, culture, age, schooling and health care levels, generating an impact on society. It is registered by the society that gives existence, tolerates and justifies whoever commits this type of violation, whose definition is manifested as any act that causes damage: patrimonial, psychological, physical and sexual, attempting against the quality of life and the environment of the woman (2).

According to Grossman (3), gender violence is any action exercised by one or more persons, intentionally causing suffering, mistreatment and manipulation, and attacking their dignity.

Gender is considered a group of cultural, political, legal and economic characteristics in which society attributes to it what it considers appropriate for men and women (4).

The first level of attention is the entrance door to health services, it solves problems and needs $85 \%$, being the first contact that the user has with health professionals (5).

The types of violence covered by this research are Patrimonial violence where the aggressor uses the mechanisms to deprive the victim of money and goods; psychological violence implies manipulation through threats and humiliations, diminishing his self-esteem; physical violence that leaves traces, bruises, hematomas, injuries and fractures being visible to other people; sexual violence violation on his sexuality using intimate and aggressive behaviors without his consent (6).

To unleash any type of violence there is a cycle that is detailed below: phase of accumulation of tension where the aggressor is irritable and unbearable and any attitude of the victim disgusts him; phase of violent explosion where the aggressions begin, threatening to end the life of the woman and her environment; phase of conciliation where the aggressor apologizes and demonstrates that he has changed and scale of violence in which the abuser gained the trust of the affected and begins again the cycle of violence (7). The risk factors that can lead a woman to become a victim of violence are Lower schooling, history of family abuse, low socioeconomic status, immigrants, alcohol and drug abuse, machismo, higher literacy rate among men (8).

According to the World Health Organization (WHO) the consequences of violence are as follows: death as $38 \%$ were killed by their partners, injuries $42 \%$, risk of alcohol abuse, contracting sexually transmitted diseases, depression, mental illness, unwanted pregnancies and abortions (9). 
According to the National Survey of Statistics and Censuses (INEC), applied in 2011, the rate of incidence of the female population according to scenarios of violence in the province of Cañar are the following: women victims of sexual abuse before the age of 18 with $86.4 \%$, having suffered violence throughout their lives with $68.7 \%$ and violence by their ex-partner with $56.3 \%$ (10).

In Ecuador, gender violence is a state problem, and despite the existence of policies and laws that contribute to the eradication of violence, there is still a high rate of violence. This is evident in the Family Relations and Gender Violence Survey, where the highest percentage is psychological (53.9\%), physical (38\%), patrimonial $(35.3 \%)$ and sexual $(25.7 \%)$. Currently, gender roles within society behave according to what our culture determines; the same ones that are learned and acquired within the family and social nucleus. (12). The present investigation was proposed with the objective of: Describe gender violence in women between the ages of 15 and 49 who come to the Azogues Health Center during the period September 2019-February 2020.

So the following hypothesis was formulated: The types of gender violence are directly related to sociodemographic factors (age, origin, ethnicity, marital status, occupation, educational level. For the first and second objectives, no hypotheses were proposed since this is a purely descriptive study. A study carried out in Ecuador on gender violence reveals that 6 out of 10 women have suffered some type of violence due to various factors that make them vulnerable; either because they suffer some type of disability, are indigenous, or because of their low socioeconomic level $(12,13)$.

Gender violence is a problem not correctly identified by the population and this would be the first barrier that must be broken to solve it satisfactorily. It is necessary to sensitize to take conscience and thus to be able to perceive in a precocious way, any type of violence and to stop it on time so that it does not unchain situations that put in risk the life of the victim (14). That is why this research is being carried out on women from 15 to 49 years old by reviewing the literature of several studies, showing a high percentage of violence, especially among indigenous women with a low socioeconomic level, low schooling, victims of violence in childhood, immigrants and couples who abuse drugs are susceptible to violence.

It will help to describe the types of gender violence, in women who come for outpatient care because in our town there is no documentation or record that specifies the situation of violence suffered by women who come to the Azogues Health Center.

\section{METHODOLOGY}

A study with a non-experimental design of descriptive, analytical, prospective and cross-sectional type with a quantitative approach was carried out in the period September 2019-February 2020, in the Health Center of Azogues. The study population was from 15 to 49 years of age who attend an outpatient clinic, excluding women under 15, over 49 and women who do not wish to participate in the research. A probability sampling was carried out where each individual has the same probability of being included in the sample; to determine the sample size, the variability of the investigated parameters was taken into account, the same that was obtained from studies acquired from the scientific literature with a population similar to that of the study, calculating with a prevalence of $60 \%$ considering that our population is finite, with a precision of $5 \%$ and a confidence level of $95 \%$ obtaining a sample size of 351 women.

For the collection of data, a Gender Violence Scale in Women (GWS) was elaborated, which was applied to a pilot sample with the students $(n=80)$ of the Azogues School of Nursing. The questionnaire was entitled: 15 to 49 years of age who attend the Azogues Health Center No. 1, explaining the reason for the study, confidentiality and anonymity, collecting sociodemographic data and questions about types of violence, with a total of 27 questions (patrimonial 7, psychological 8, physical 7 and sexual 5). The LIKERT scale was used with the following items: many times, few times, once and never, the information was taken from the National Institute of Statistics and Census (INEC), elaborated by the researchers and validated by experts: Mgs. Maritza Galán, Mgs Luis Astudillo, Mgs. Andrés Ramírez.

The descriptive analysis was used to know the sociodemographic characteristics that are frequently presented. As well as the analysis by percentages in order to know the most common types of violence by recording the data in tables, the correlational analysis between the variables with Spearman's Rho correlation was carried out, as this test is adequately vigorous in the face of the fulfillment of non-parametric assumptions.

\section{RESULTS}

In relation to the sociodemographic characteristics (Table 1), the following results were obtained: age was classified in ranges according to the World Health Organization (WHO), which includes adolescence, young adult and adult, with a higher prevalence in young adult with $57.3 \%$, and most of them living in urban areas with $58.7 \%$, most of them being of mixed race, which represents $91.7 \%$. 
ISSN No:-2456-2165

Most of the women were single (38.7\%), followed by married women $(32.2 \%), 39 \%$ of whom were housewives, and $37.9 \%$ of whom had completed secondary school. It is important to note that a minimum percentage of $0.6 \%$ of the population has a fourth level of education and the same percentage has no education at all.

\begin{tabular}{|c|c|c|c|}
\hline & & $f$ & $\%$ \\
\hline \multirow{3}{*}{ Age } & Adolescents & 57 & 16,2 \\
\hline & Young adult & 201 & 57,3 \\
\hline & Adult & 93 & 26,5 \\
\hline \multirow[t]{2}{*}{ Source } & Urban. & 206 & 58,7 \\
\hline & Rural. & 145 & 41,3 \\
\hline \multirow[t]{4}{*}{ Ethnicity } & Indigenous. & 24 & 6,8 \\
\hline & Mestizo. & 322 & 91,7 \\
\hline & Afro-Ecuadorian. & 3 & 0,9 \\
\hline & Other. & 2 & 0,6 \\
\hline \multirow[t]{6}{*}{ Marital status } & Single. & 136 & 38,7 \\
\hline & Married. & 113 & 32,2 \\
\hline & Free Union. & 67 & 19,1 \\
\hline & Separated. & 13 & 3,7 \\
\hline & Divorced. & 18 & 5,1 \\
\hline & Widowed. & 4 & 1,1 \\
\hline \multirow[t]{5}{*}{ Occupation } & Paid work. & 63 & 17,9 \\
\hline & Occasional work (underemployed). & 34 & 9,7 \\
\hline & Unemployed. & 12 & 3,4 \\
\hline & Housewife. & 137 & 39,0 \\
\hline & Student. & 105 & 29,9 \\
\hline \multirow[t]{8}{*}{ Level of education } & Complete primary school. & 63 & 17,9 \\
\hline & Primary incomplete & 19 & 5,4 \\
\hline & Complete secondary school. & 133 & 37,9 \\
\hline & Incomplete secondary. & 95 & 27,1 \\
\hline & Third level. & 37 & 10,5 \\
\hline & Fourth level. & 2 & 0,6 \\
\hline & No studies & 2 & 0,6 \\
\hline & Total & 351 & 100,0 \\
\hline
\end{tabular}

Table 1:- Socio-demographic characteristics.

In relation to the types of violence, data is revealed that $22.5 \%$ have suffered patrimonial violence $(19.7 \%$ one time and $2.8 \%$ few times), $45.6 \%$ have been victims of psychological violence (36.5\% one time, $8.3 \%$ few times and $0.9 \%$ many times), $20.8 \%$ presence of physical violence (16.8\% one time, $3.7 \%$ few times and $0.3 \%$ many times), according to sexual violence $13.1 \%$ ( $10.3 \%$ one time, $2.3 \%$ few times and $0.6 \%$ many times). 
ISSN No:-2456-2165

\begin{tabular}{|c|c|c|c|c|c|c|}
\hline & & $f$ & $\%$ & & $f$ & $\%$ \\
\hline \multirow[t]{3}{*}{ Heritage } & Never & 272 & 77,5 & \multirow[t]{2}{*}{ Absence } & & \\
\hline & Once & 69 & 19,7 & & 272 & 77,5 \\
\hline & Rarely & 10 & 2,8 & Presence & 79 & 22,5 \\
\hline \multirow[t]{4}{*}{ Psychological } & Never & 191 & 54,4 & \multirow[t]{2}{*}{ Absence } & \multirow{2}{*}{191} & \multirow{2}{*}{54,4} \\
\hline & Once & 128 & 36,5 & & & \\
\hline & Rarely & 29 & 8,3 & \multirow[t]{2}{*}{ Presence } & \multirow[b]{2}{*}{160} & \multirow{2}{*}{45,6} \\
\hline & Many times & 3 & 0,9 & & & \\
\hline \multirow[t]{4}{*}{ Physics } & Never & 278 & 79,2 & \multirow[t]{2}{*}{ Absence } & \multirow{2}{*}{278} & \multirow{2}{*}{79,2} \\
\hline & Once & 59 & 16,8 & & & \\
\hline & Rarely & 13 & 3,7 & \multirow[t]{2}{*}{ Presence } & \multirow{2}{*}{73} & \multirow{2}{*}{20,8} \\
\hline & Many times & 1 & 0,3 & & & \\
\hline \multirow[t]{5}{*}{ Sexual } & Never & 305 & 86,9 & \multirow[t]{2}{*}{ Absence } & \multirow{2}{*}{305} & \multirow{2}{*}{86,9} \\
\hline & Once & 36 & 10,3 & & & \\
\hline & Rarely & 8 & 2,3 & \multirow[t]{2}{*}{ Presence } & \multirow{2}{*}{46} & \multirow{2}{*}{13,1} \\
\hline & Many times & 2 & 0,6 & & & \\
\hline & Total & 351 & 100,0 & Total & 351 & 100,0 \\
\hline
\end{tabular}

Table 2:- Types of Violence -Absence and Presence of Violence

The relationship between sociodemographic characteristics and types of violence is as follows: age is related to patrimonial, psychological and physical violence, with a positive significance level CC:220 >0.005, marital status is related to all types of violence in a positive way, educational level is related to patrimonial, psychological and physical violence with a negative significance level CC:-151<0.005. According to the analysis of this table the types of violence have no relationship with origin, ethnicity and occupation.

\begin{tabular}{|c|c|c|c|c|c|}
\hline & & Heritage & Psychological & Physics & Sexual \\
\hline \multirow{2}{*}{ Age } & Rho &, $220^{* *}$ &, $200^{* *}$ &, $227^{* *}$ & 0,091 \\
& $\boldsymbol{p}$ & $\mathbf{0 , 0 0 0}$ & $\mathbf{0 , 0 0 0}$ & $\mathbf{0 , 0 0 0}$ & 0,089 \\
\hline \multirow{2}{*}{ Source } & Rho & 0,011 & $-0,046$ & $-0,006$ & $-0,064$ \\
\cline { 2 - 6 } & $\boldsymbol{p}$ & 0,831 & 0,392 & 0,917 & 0,232 \\
\hline \multirow{2}{*}{ Ethnicity } & Rho & 0,007 & 0,036 & 0,016 & 0,062 \\
\cline { 2 - 6 } & $\boldsymbol{p}$ & 0,891 & 0,499 & 0,770 & 0,246 \\
\hline \multirow{2}{*}{ Occupation } & Rho &, $284^{* *}$ &, $228^{* *}$ &, $270^{* *}$ &, $116^{*}$ \\
\cline { 2 - 6 } & $\boldsymbol{p}$ & $\mathbf{0 , 0 0 0}$ & $\mathbf{0 , 0 0 0}$ & $\mathbf{0 , 0 0 0}$ & $\mathbf{0 , 0 3 0}$ \\
\hline \multirow{2}{*}{ Level of education } & Rho & 0,046 & $-0,028$ & $-0,034$ & 0,026 \\
& $\boldsymbol{p}$ & 0,391 & 0,596 & 0,520 & 0,626 \\
\cline { 2 - 6 } & Rho &,$- 151^{* *}$ &,$- 133^{*}$ &,$- 114^{*}$ & $-0,005$ \\
\hline
\end{tabular}

Tabla 3:- Correlación entre características sociodemográficos y tipos de violencia.

\section{DISCUSSION}

The purpose of this study is to describe the types of violence suffered by women in couple relationships, including patrimonial, psychological, physical and sexual violence, in order to know the sociodemographic factors and the relationship with violence, in women who come for outpatient care at the Azogues Health Center.

This research was carried out with the participation of women from 15 to 49 years old who were in the waiting room, where the analysis of the sociodemographic characteristics gave a higher prevalence in the young adult population, whose occupation is to be a housewife, perhaps this is one of the reasons for the economic dependence of the couple, preventing them from breaking the bonds of violence suffered day by day in silence.
Cano et al, in their study of women who attend primary health care, in the results they show that the majority of the women belonged to urban areas with $63.8 \%$, compared to $58.7 \%$ in this article, $40.2 \%$ had primary and $27.2 \%$ secondary education, results similar to our study where the women had completed primary education $(17.9 \%)$ and $37.9 \%$ had completed secondary education (15).

Jaen et al. (16) mentioned similar results to the present study in relation to the types of abuse that agree with the types of violence with greater presence in the study are psychological violence $32 \%$, physical $19 \%$, economic $14 \%$ and sexual with $8.5 \%$ similar data to the present article with respect to psychological violence $45.6 \%$, patrimonial 22.5 , physical $20.8 \%$ and sexual $13.1 \%$, the use of closed questions facilitates the women to give a concrete answer, ; 
the findings of this study show that violence continues to exist in the population where rights are violated and women are viewed as sexual objects.

Perez Et al. in his study against women in the couple, a study made in the primary attention reveals data where $25.6 \%$ were single, occupation housewife $35.3 \%$, level of secondary education $23.7 \%$, type of physical abuse $5.4 \%$, emotional $16.9 \%$ and sexual $3.7 \%$, there is relation with respect to our study with the types of violence, since at the present time still exists a high index of cases of violence where the woman is violated $(17,18)$.

\section{CONCLUSION}

The results of this research reveal that a considerable proportion of outpatient clients suffer from some form of violence. According to the sociodemographic characteristics, there is a high percentage of young adult population that resides in the urban area, of mixed ethnicity, single marital status and complete secondary schooling.

The different types of violence suffered by the women who come to this health center are evident, since the most frequent is psychological, patrimonial, physical and sexual violence. These situations make it difficult for the victim to leave the abusive relationship due to various situations such as submission, fear, lack of support from the family, significantly affecting the victim and the environment.

This is why it is considered important to intervene immediately and help the abused women to prevent complications; health personnel play a fundamental role in this space, to act and detect these situations and to detect this public health problem.

\section{Conflicts of Interest}

The authors do not report conflicts of interest.

\section{ACKNOWLEDGEMENT}

To the Doctorate in Health Sciences, University of Zulia (Venezuela), to the Psychometrics Laboratory of the Center for Research, Innovation and Technology Transfer of the Catholic University of Cuenca and to the Nursing Career of the Catholic University of Cuenca, headquarters of Azogues.

\section{REFERENCES}

[1]. Fernandez M. Health and Gender Violence in Latin America: A Gender-Sensitive and Socio-sanitary Reading. 2016.2 Available from: https://www.salud.gob.sv/archivos/pdf/cursos/Becas/C urso_UISP-6-2016/presentaciones/dia-3/02-CatedraUISP-Sara-Fernandez-28-de-Noviembre-2016.pdf.

[2]. Calvo G, Camacho R. Gender-based violence: evolution, impact and keys to addressing it. Enfermería Global. 2014; 13 (3): 3.
[3]. Marcano A, Palacios Y. Gender violence, categorization, causes and consequences. Comunidad y Salud. 2017; 15 (1): 73-85.

[4]. UNICEF. Hendel Gender perspective ;2017 Available from:https://www.unicef.org/argentina/sites/unicef.org .argentina/files/2018-04/com1_PerspectivaGenero_WEB.pdf.

[5]. Virgnolo J. Levels of prevention and primary health care. Archivo de Medicina Interna. 2011; 33(1):11-14.

[6]. Antunes M, Montalbán M, Signorini H. Discourse on violence against women in a virtual forum: Presences of the gender framework. 2013;27(2):111-115.

[7]. Yungeros A. Violence Against Women: Concepts and Causes. Revista Castellano-Manchega de Ciencias Sociales. 2014; 18:147-159.

[8]. Puente A, Ubillos S, Echenurua E, Páez D. Risk factors associated with intimate partner violence against women: A review of recent meta-analyses and studies. Anales psicológicas. 2016;32(1): 295-306.

[9]. WHO. WHO report highlights violence against women as "a global health problem of epidemic proportions". [Online].;2013[cited 2020 enero 17 Available

from:https://www.who.int/mediacentra/news/relaces/2 013/violencia_against_women_20130620/es/.

[10]. INEC. Compendio Estadístico 2014. [Online].; 2014 [cited 2020 enero 17 Available from: https:/www.ecuador en cifras .gob.ec/documentos/webinec/Bibliotecas/Compendio/Compendio2014/compendio_estadisticos_2014.pdf.

[11]. Chávez M, Méndez A. Gender Violence in Ecuador. Publishing Magazine. 2016;3(8):104-115.

[12]. Illescas M, Tapia J, Flores E. Socio-cultural factors that influence women who are victims of domestic violence. Revista Killkana Sociales. 2018;2(3):187196.

[13]. Piedra J, Rosa J, Muñoz M. Intervention and Prevention of Gender Violence: An approach from social work. Global Social Work. 2018;8(14):195216.

[14]. Lemus O, Acosta Y, Damas L. Domestic violence against women. Revista Cubana de Enfermería. 2016;32(1):98-109.

[15]. Cano L, Berrocoso A, Arriba L, Quirós L, Alamar J, Cardo A. Prevalence of gender-based violence in women who attend primary care. Revista Clínica Médica Familiar. 2010;3(1):10-17.

[16]. Jaen C, Rivera S, Amorín E, Rivera L. Partner Violence in Women; prevalence and associated factors. Acta de Investigación Psicológica. 2015;5(3):2224-2239.

[17]. Ruiz I, Plazaola J, Blanco P, González J, Ayuso P, Montero M. Violence against women in the couple. A study in the field of care. Primaria Gaceta Sanit. 2006:20(3):202-208.

[18]. Ramírez-Coronel AA., Martínez-Suárez PC, CabreraMejía JB, Buestán-Andrade PA, Torracchi-Carrasco E, Carpio MG. Habilidades sociales y agresividad en la infancia y adolescencia. Archivos Venezolanos de Farmacología y Terapéutica. 2020;39(2):209-214 